\title{
Is Gabola a Decolonial Church or Another Trajectory of Freedom of Religion in Post-Colonial South Africa? Rethinking Ethical Issues in Religious Praxis
}

\author{
Bekithemba Dube \\ Faculty of Education, University of the Free State, Qwaqwa Campus, Phuthaditjhaba 9866, South Africa; \\ dubeb@ufs.ac.za
}

Received: 30 January 2019; Accepted: 26 February 2019; Published: 7 March 2019

\begin{abstract}
In this paper, I interrogated the Gabola church in terms of its origins, purpose and its distinctiveness as a postcolonial manifestation of freedom of religion in South Africa. I answered two questions, is Gabola church a representation of a decolonial church and could it be a manifestation of trajectories of the postcolonial ill-defined freedom of religion? In responding to these questions, I used decoloniality, a theory whose agenda among many others is geared to usher a future free from oppression, where all can participate in modernity and in postmodernity. Data was generated through participatory action research. The approach enabled us to unearth the theology of Gabola, philosophy and the gap they seek to fill in the religious space. Ten Gabola church members and five church members from a mainline Christian movement participated in this research. The findings indicated that Gabola church presents a new religious movement that is socially inclusive, that seeks to promote social justice and social transformation. On the other hand, the research revealed that the lack of a regulating body for religious movement is the reason for the rise of questionable movements such as Gabola, a serious threat in the praxis of the Christian faith. To this end, I concluded that while freedom of religion is a good idea in line with the decolonial move, there is a need for participative and collaborative regulation of religious movement to eliminate criminal elements that overshadowed the beauty of religion manifested through 'unthinkable' ethical irregularities.
\end{abstract}

Keywords: Gabola Church; Decolonial Church; Conventional church; ethics and education

\section{Introduction}

Despite various philosophies, with others stipulating that religion will soon disappear from public life (Brittain 2012, p. 208), religion continues to be a force to be reckoned with. In fact, religion has not disappeared from public life in postcolonial South Africa, but continues to be a powerful source of good, evil (Dreyer 2007), and unending controversy. The controversy arises as some emerging religious movements are characterised by exhortation, violation of human rights, and the promotion of patriarchal tendencies among many (Dube and Nkoane 2018). To develop this argument of controversy, for the purpose of this article, I focus on Gabola 'church'. Before unpacking it in detail, it should be noted that South Africa in its Bill of Rights, gives space for the freedom of religion. The constitution of the Republic of South Africa (1998) states that, "everyone has the right to freedom of conscience, religion, thought, belief, and opinion". In addition, Section 31(1) (a) states,

Persons belonging to a cultural, religious, or linguistic community may not be denied the right ...

(a) To enjoy their culture, practise their religion, and use their language.

However, its implementation is without controversy and, to some extent, leads to loss of human lives and the promotion of unethical practices in cases such as of the Seven Angels Ministry (Dube 2019). 
Describing in detail, Kenny (2017) argues that the South African religious landscape is characterised by unconventional churches and colourful preachers who employ all kinds of outlandish or bizarre rituals to attract parishioners. To this end, a new religious movement has emerged, the Gabola church. The rise of the Gabola church has been received with mixed feelings from the Christin community and, at the same time, more questions have been raised, especially on religious ethical issues, as will be discussed. Thus, for the sake of this article, I frame the debate and unfolding of the paper cognisant of two questions. Is Gabola is a decolonial church or another trajectory of postcolonial practice of religion? Thus, these questions form the centre of this article and were used to glean data from the participants.

\section{Definition of Terms}

In this section, I define various terms that are used in this paper. The term postcolonial is traced as early as 1961, with the works of Frantz Fanon who provided the work that initiated what has become the present postcolonial theory amongst academics by his publication The Wretched of the Earth, which was a sequel to his book Black Skin, White Masks, published in 1952 (Adamo 2011). The terms also referred to the decolonisation of the future by destabilising the way of thinking of the developed world in order to create space for the subaltern or marginalised groups to speak and produce alternatives to dominant discourse (Adamo 2011). For the sake of this paper, postcolonial refers to the post-1994 period, where a new dawn emerged in the political landscape of South Africa (South Africa gained political independence in 1994) and ushered in a new constitution in 1996 that recognised the need to respect various religious practices. The word religion is used very loosely in this paper; in many cases, it refers to the Christian faith, cult, or group of believers or adherents characterised by a claim that they believe in a divine being and their existence to push God's agenda. Conversational churches of theologies as used in this article refer to bible-based churches, which were formed by missionaries whether from the Global North or Global South. In some cases, these churches are also referred to as mainline churches, characterised by believing in the priesthood of all believers, maintaining a good lifestyle exemplified by maintaining standards of purity, love for all and forbidding followers to take alcohol.

\section{Background of Gabola Church}

The Gabola church came to the religious landscape of South African in 2017 under the custodianship of Bishop Tsietsi Makiti, 52. He is the founder of the church and the brains behind the idea (Kwalimva 2017). The Gabola is a Sotho term meaning drinking or "have a sip" (Makhethwa 2017). The church is characterised by worship in taverns, which are used as sites for worship. The church members eventually become patrons. The church is predominately in cities attracting followers especially among the youths and beer lovers. The church has drawn attention to many because of their philosophy towards drinking of beer. The church, unlike other 'churches', invented new ways of baptism, which was never thought of before, which is, using beer as a form of baptism, at least by conventional churches. Kwalimva (2017), commenting on the Gabola baptism, says, "A church in South Africa has introduced an unorthodox way of baptizing its faithful-your favourite alcoholic drink replaces water". The church theology and praxis is centred on drinking all sorts of alcoholic beers, basing drinking during church service in John chapter 2. Unlike the Roman Catholic that allows its members to drink beer in private spaces, Gabola believes that drinking should take place during the church service. Thus, as argued by Kwalimva (2017), congregants at the Gabola church have also been given the go-ahead to drink alcohol during church services. As such, the church does not follow a prescribed order of doing church as advocated by conventional churches.

The paper follows two paths, which are informed by the above questions. One suggested by Jared (2017) is that the Gabola church has rewritten and redefined what a 'standard church' ought to look, behave, and preach like in a postcolonial space. Apart from redefining the order of worship and doing church, Mathape (2018) says Gabola church's form of Christian religious expression is probably the first of its kind in the world. The other path indicates that the Gabola church has diverted from what 
has been considered 'ordinarily' accepted by conventional religious followers. Describing the second path, the South African Council of Churches has described Gabola church as "[a] cult and disgrace to Christianity", a representation of "the end of times" (Mathape 2018) and deviant social organisation masquerading as religion, and an opposite of legitimate religion (Chidester 2003, p. xx). Given these two paths, I agree with Beyers $(2014$, p. 1), that the issue of religion and its praxis needs to be put on the table again for debate, and Mpofu (2017) is of the view that putting it on the table is an urgent business especially with questionable postcolonial praxis of religion.

\section{Theoretical Framing: Decoloniality}

In interrogating the Gabola church, I used decoloniality theory. Decoloniality allows a new way of thinking, doing and imagining a better future (Ndlovu-Gatsheni 2015, p. 46), and as such it fits into interrogating the Gabola church to see if it offers a new thinking for a better religious praxis. Through decoloniality, the attempt is remaking the world of the enslaved, colonised, and exploited peoples to regain their ontological density, voice, land, history, knowledge, and power (Ndlovu-Gatsheni 2015, p. 23). The theory rejects modernity, which is located in the oppressed and exploited side of the "colonial difference", and rather argues "towards a decolonial liberation struggle to a world beyond eurocentered modernity" (Ramón 2011, p. 12). This modernity is evident in the organisation of power, of identity or humanity and humanism and in the structures of knowledge (Zondi 2016, p. 20), as is highly reflected with postcolonial religious movements in South Africa. Thus, decoloniality is the thinking and practices from peoples and parts of the world that have experienced even the enlightenment itself as a darkening of the world and have endured modernity as dehumanisation (Mpofu 2017). To this end, and in the context of oppression and dehumanisation, decoloniality as a theory seeks to address injustice (Mpofu 2017). By the same token, it can be argued that decoloniality, then, means working toward a vision of human life that is not dependent upon or structured by the forced imposition of one ideal of society over those that differ (Mignolo 2007). In the context of this study, decoloniality is pertinent as I interrogate Gabola church practices in the context of social justice with the need for church members to participate in the modernity and postmodernity that is free from the coloniality of power, knowledge, and being as manifested in some of the postcolonial religious movements. Decoloniality allows us to interrogate Gabola as an emerging church, which when it exhibits decolonial tendencies, it must be given space in the contested religious space, or on the other hand, challenge any processes that exhibit dehumanisation and those that promote dehumanisation. With this ambivalence, it is then difficult to identify whether the church fits within the broader spectrum of the Christian faith, cult, or some new movement that will be categorised with time.

\section{Methodology: Participatory Action Research}

I have chosen participatory action research (PAR) because this approach to Gabola church research allows an "investigation of actual practices and not abstract practices and learning about the real, material, concrete, and particular practices of particular people in particular places" (Kemmis and McTaggart 2007, p. 277). PAR involves "identifying the rights of those concerned by the research, and empowering people to set their own schemas for research and development, thereby giving them tenure over the process" (Cornwall and Jewkes 1995, p. 1674). Lopez (2015, p. 229) indicates that the PAR approach directly challenges the traditional ways of doing research, and that its focus is on benefitting the community in which the research is taking place. PAR responds to a reality that states that conditions of injustice are not natural, but are produced and can therefore be challenged (Loewenson et al. 2014, p. 14). Tshelane (2013, p. 417) argues that PAR involves a "collaborative effort to address specific systems. It is a cyclical and reflective research design that focuses on problem solving and improving work practices". In addition, PAR groups "aspects of popular education, community-oriented research, and action for social change to promote marginalized communities, where the quest is to unearth the causes of social inequality and consequently the solution to alleviate 
the identified problems" (Williams and Brydon-Miller 2004, p. 245). In line with PAR, I attended several of the Gabola church services with some of the participants of the study. This was essential to gain access to information from the church members. I also engaged other participants from mainline churches to voice their views on the new church and highlight their feeling on the new church. During the last meeting, I managed to have a focal discussion with some members of Gabola and the mainline church to discuss their views on the new movement.

\section{Data Analysis}

The data collected were analysed through the model suggested by Laws et al. (2003), which provides seven steps:

Step 1: Reading and rereading all the collected data: The data from the interviews and focus group discussion were read and reread to get the essence on the Gabola church and their beliefs.

Step 2: Drawing up a preliminary list of themes arising from the data: Major issues and themes were identified and arranged according to the research question of the study.

Step 3: Rereading the data: By rereading the data, I checked if the themes I had identified corresponded with what the participants said and with the research questions.

Step 4: Linking the themes to quotations and notes: The themes emerging from the data were linked to various scholarly views.

Step 5: Perusing the categories of themes to interpret them: During interpretation of the data, I remained cognisant of the research question.

Step 6: Designing a tool to help discern patterns in the data: Through this, I was able to determine the patterns during data analysis.

Step 7: Interpreting the data and deriving meaning: I identified themes that then became the subheadings.

\section{Ethical Issues}

This paper is part of a bigger project of capstone research and was ethically cleared by the University of the Free State, UFS-HSD2017/0998. Thus, the study adhered to ethical practices such as protection of the participants, given the sensitiveness of religious issues. I also ensured that pseudonyms were assigned to participants. I also ensured the participants that the data obtained would only be used for academic purposes, which is to enhance the praxis of religion for sustainable development. To ensure reliability of the analysed data, I used a member-checking process (Birt et al. 2016, p. 1802; Bygstad and Munkvold 2007, p. 1; Gunawan 2015, p. 10) to ensure that my findings reflect what the participants gave during the participatory action research.

\section{Findings and Discussion}

\subsection{Decolonial Apsect of the Gabola Church}

Accepts Outcast from Other Churches

From the research it emerged that the Gabola church represents a decolonial church through its non-segregative policy. The participants revealed that Gabola gave them an opportunity to drink beer that would not be permitted under conventional circumstances. They also indicated that some of the churches have too many expectations, which in some cases becomes a burden, but with Gabola, the church has no policing or too many expectations, making the worship and participation in church activities engaging and rewarding. Mandlovu commenting on this noted that, "Gabola is a good church, we are free here, we are not judged. We do all we want and such freedom is not there in other churches". Jared (2017) confirms the observation by Mandlovu and notes that Gabola church is open to all people regardless of their past and present conditions, especially in relation to the consumption of alcohol. Makiti stated that the church accommodates people who are not welcome at other churches 
(Jared 2017). However, despite this stance, people, especially from conventional theology, generally dismiss and do not tolerate the Gabola approach. Despite the dismissiveness towards Gabola, at least according to the adherents, Gabola offers a philosophy behind the church that creates an environment where consumers of alcohol—who are condemned by mainstream churches—can find a home (Tau 2017). Accommodating all, regardless of their standing in society, speaks a lot in terms of inclusivity and promotes the agenda of decoloniality where all need to partake in modernity as people of equal value with those who exclude them. To this end, Gabola has become like a city of refugees where people in Biblical times could run for safety. In other ways, Gabola church has filled a gap created by conversational churches through acts of excommunication and dismembering seemingly wayward behaviours.

\subsection{Eradication of the Tithing System}

The Gabola church has arguably brought a sigh of relief to people who have viewed some churches as money mongers, which are described by Epondo (2015) as churches that are run like insurance companies owning sanctimonious spiritual powers, playing on the hopes and fears of their followers, in exchange for generous tithes. Gabola church does not require its members to contribute tithing, describing the practice as an exploitation of the poor. During the visit at the church, there was no giving time but members were free to use their money to buy beer. When asked about the rationale behind such an approach to the order of service, participants were quick to praise the new church on its approach to giving. One member was jubilant and noted that, "with Gabola church our monies are very safe, we use it to buy beer unlike in many churches where money is given and only the pastor benefits from. Here with or without money, we worship God". Makhethwa (2017) confirms this observation by indicating that Gabola does not take tithes from congregants. The money we use in church is just buying their own drinks while we conduct our services. In support, Molobi (2017) argues that Gabola does not ask people to give us money, our members use their money to buy booze, and sometimes people give away their money to churches even though they are poor. To some, this is seen as a decolonial approach to doing church. It is common knowledge that some new religious churches are known for extortionist tendencies, where the poor give all they have to please the few especially religious leaders. Confirming this, The Commission for the Protection of the Rights of Cultural, Religious and Linguistic Communities (2015) (henceforth (CRL 2015)) noted that some religious movements refuse to share financial statements, signatories to the bank accounts, deeds or leases of the land. To this end, tithing becomes a thorny issue in many churches, thus to some Gabola church brings relief to the masses, especially the poor who have suffered from mafia prophets. However, this does not correlate with the mainline theology of conducting service since tithes are generally in the order of service. Thus, no-payment of the titles seemed to place Gabola church at a decolonial space and perhaps confirm the teaching of the New Testament where tithes are arguably not part of the teaching of the gospel writers and apostles.

\section{Community Empowerment}

For the church to be relevant, it should, among many other things, empower its people and ultimately find ways to contribute to social transformation and development. To this end, the Gabola church seeks to fulfil the role by empowering youths. One Mzondiwa noted that, "as a church we are in the process of starting projects that will benefits youth, here it's not about church only but how we should survive after church". In addition, Zwelani argued, "that conducting churches in taverns is a strategic move to locate youths for life skills projects. Youths are many and because of unemployment they are always in taverns thus skill building it taken to where youths are". Adding to this notion, Jared (2017) noted that the church is not about alcohol only; we have programmes that empower the youth. We started soccer teams and a studio for artists and photographers. The other pipeline projects included poultry and building. To this end, this can be seen as a decolonial move where adherents are emancipated out of poverty through various life skills projects. 


\subsection{Ordination Processes}

The Gabola presents a new phenomenon in the praxis of faith. It is common knowledge that among the mainline churches, pastors or bishops undergo theological training in order to qualify for the service of the ministry. However, with Gabola church the criterion is that the owner of the tavern automatically becomes the pastor of the church. While the process appears more economical to cover accommodation costs, it does not address the capabilities and moral uprightness expected from the religious leaders opening a serious challenge to the polity of the Christian faith. This, according to the participants, is a move aimed to secure venues for church service at no cost. Ndozi, commenting on this said, "at Gabola the bar is not high like other churches that require lot of training for pastors, here own a tavern and you become a pastor. I believe it makes life easy for leaders since there are not costs for training and it addresses vacuum in church polity". While Gabola members may appreciate the practice, it presents various trajectories especially in the professionalisation of religious occupation. It exposes the church to being hijacked by criminals who can use the fluidity and flexibility of the church to acquire a position and use it to commit various atrocities.

\subsection{Champions' Social Justice}

The rise of the Gabola is also associated with the need for churches to be socially inclusive. According to the church members who participated in this research, the church has brought a new hope for the masses that have been rejected systematically or by design from the mainstream churches. As such, according to the Gabola members, this speaks of social justice. As used in this research, social justice is based on the idea of a society that ensures fair treatment and a just share of the benefits of society for individuals and groups (Monychenda 2008, p. 19). Speaking of his role in the spiritual dimension, Bishop Tsietsi Makiti argues that people must remember that I am sent by God to be the voice of the voiceless (Molobi 2017), implying that he is the defender of justice. In defending the voiceless, the church seeks to use the gospel to eliminate various injustices such as sexual abuses, money laundering, and child abuse among many others (Dayiman and Ntshobane 2018). This approach will help adherents who, through abuse, are left with no voice and no will (Freire 2000, p. 144). Thus, regarding the stance to champion social justice by Bishop Makiti and Gabola structures, Alvesson and Willmott (1992, p. 432) are right to argue that some "individuals and groups become freed from suppressive social and ideological situations, particularly those that place socially unnecessary precincts upon development and enunciation of human consciousness". By being the defender of the poor, as claimed by Gabola, it places them in the space of being decolonial, which can contribute significantly to the transformation of the South African society that is characterised by various injustices.

In line with social justice aspect, the church gives its members a laissez-faire approach to conducting church. It then does not put stringent laws among its church members. Some churches are notorious for enacting stringent laws that then become a burden to the followers such as compulsory attendance, tithing, and total obedience to a leader or leaders, or even in some cases do what Chidester (2003) refers to as strategic distancing from the rest of the members of community to allow each control. But with Gabola, arguably we see a decolonial church through adopting liberal approaches to Christian faith.

\section{Questionable Practices Negating Decolonial Church}

Apart from the church playing a pivotal role to decolonise postcolonial religion in South Africa, the Gabola church has exhibited some of the questionable practices, which, in the eyes of conventional religious movements, they are deemed ungodly and likely to bring the name of God into disrepute. Thus, there is a need informed by United Nations Educational Scientific and Cultural Organization (UNESCO 2011, p. 17) to interrogate and problematise some practices since some aspects of religious systems and knowledge impinge on national and global mind-sets, and the development of critical 
and democratic citizens. Cognisant of this, in the following section, I highlight some of the findings that make certain people argue that the church is one of the examples of an ill-defined freedom of religion and more a trajectory of postcolonial praxis of Christian faith.

\subsection{Re-Writing of the Bible}

In an endeavour to contextualise the Christian faith to the African identity and representation, the Gabola church argues for the rewriting of the Bible. While the idea may seem noble, the suggestion has made the Gabola church unpopular and could be labelled anti-God. The foregoing argument is cemented by Bradley (2012, p. 1), who argues that some churches and their leaders deploy negative portrayals of the church, characterising them as "failing", "in crisis", or otherwise failing to live up to Christian standards. The participants, while appreciating the Gabola church, were not comfortable with the need to rewrite the bible. Thus, the need to rewrite the bible has placed the church as one of the trajectories of postcolonial religion as the bible has been deemed a sacred book, which must be followed, at least from a conventional theological orientation. Rewriting can raise more problems where criminal elements can hijack the project and insert controversial issues that might compromise the ethical standard of the Bible, which are generally appreciated and accepted. The need to rewrite the Bible can overshadow the beauty that the church wishes to offer in an effort to transform the South African society through religion.

\subsection{Segregation of Women}

While the church boasts being democratic and accommodative of the members, which are not allowed in other churches, the challenge is that the Gabola church has not structured itself to welcome women in the context of church and boozing at the same time. During this research, various women could be seen milling around taverns with only few of them inside the church. According to the participants, the women that take part in the service are regular customers, while those milling outside are aspirant adherents because of the fear of what people could say about the unconventional methods of worship or because of the unclear structure for the inclusion of women. According to the Bishop, as cited by Jared (2017), women are not allowed because drunk men may start troubling these women. Given this context, it becomes difficult for one to qualify the church as a decolonial church given the lack of structures that allow women to be part of the church. In fact, it can be argued that it promotes patriarchal tendencies, where men still occupy predominant positions, which is of course against the provisions to create and champion democracy through Christian theology. It also presents challenges of destroying family ties, which in most cases are championed by religious institutes (Damaris and van Klinken 2018), especially with mainstream religious movements. Thus, Gabola church needs a clear theology on the inclusion of women in all structures. Through this, women are brought into the ontological being space, which can contribute to reduced abuse of women and more so their marginalisation in social structures.

\subsection{Love of Power and Recognition}

Some have seen the Gabola church as one of the gimmicks used by power-seeking people and religion to offer an easy access to power and recognition at least in the lens of conventional church. Thus, the sentiments by some participants in this research are concurred by Dreyer (2007), who eludes that religion in a modern, secular, postcolonial Africa also provides opportunities for religion to be exploited in power struggles. This is based on religion, class, race, gender and all the other boundaries that are continually being revived by those in power or those seeking power. Zwane, commenting on Gabola church, said, "this is just a project of being popular. This guy wants to be known and he might want to get a political office". Cognisant of this observation, some people have used religion to ensure access to different offices and privileges. While being ambitious is ideal for progress society, it must be done in respect of other people and cognisant of the need to promote human rights and dignity. 


\section{The Way Forward to Religion in Global South}

Either the Gabola church is decolonial or another example of a trajectory of postcolonial religion, it is becoming unavoidable that freedom of religion is examined carefully and thoroughly without infringing upon any rights of people. While religious rights are or should be observed, it is important that the argument of freedom of religion be examined in light of human rights, respect for human dignity, and, at the same time, in obedience of a deity. Again, there is a need for better ways to theorise religion, of critiquing and taking religious struggles for the liberation from hegemonic forces forward in contemporary religious conjecture (Ndlovu-Gatsheni 2015, p. 23). Religious practices, underpinned in a decoloniality lens, offer an opportunity for reframing freedom of religion in the milieu of human rights. The time has come for a decolonial turn, in order to transform and rethink the religious narrative (Zondi 2016, p. 20). In response to Zondi's observation, I argue that,

[I]n the long run, society should find ways to protect people, religion-related abuse and help religion evolve in the direction of better treatment of people. (Bottoms et al. 1995, p. 109)

In this regard, in response to Bottoms et al. (1995, p. 109), I propose the following: regulation of religion, reintroduction of religion and training of religious leaders on human rights.

\subsection{Regulation of Religion}

The regulation of religion in South Africa is now a topical issue, which is becoming desirable yet cognisant for the need to respect the constitution, especially on freedom of worship (Dube et al. 2017). Thus, it is not always true that when governments relax restrictions on religion and treat all groups equally, greater societal tolerance and civility ensue (Hertzke 2012), for example, the Seven Angel Ministry case (Dayiman and Ntshobane 2018). Relaxing of religious practices can be dangerous, especially when some religions are exhibiting some questionable and unethical practices that, at least in the lens of decoloniality, need to be exorcised or challenged for the good of all. Thus, a regulation seems inevitable, as Lunn (2009, p. 939) argues that some religious practices have become "[an] impediment to economic advancement, and irrelevant for modern societies". While regulation of religion is doable and desirable, it should, however, be increasingly consultative so that no religious group or leader may feel that the regulations of religion are targeted on him or her. A consultative process has the impetus to establish a framework of human rights and enact ethical issues given the church stance on alcohol and use of taverns as religious sites. In support of this, Reginald (2017) argues that religious leaders need to enter into dialogue with all like-minded people to combat the evil influences. Furthermore, issues of safety of the religious followers, especially women and children, should be regulated given the context of taverns and behaviours of other patrons when under the influence of alcohol. In this way, and in particular in the lens of decoloniality, praxis of religions in a regulated format in respect of human rights is repositioned as national spiritual capital, as critical assets in reimaging social reconstruction and transformation (Kaunda and Kaunda 2018).

However, regulation of religion may present various trajectories, especially on the freedom of religion and religion itself. In some countries, the regulation has become a source of unending conflict between religious adherents and the state or among religious adherents (Donald and Howard 2015). This implies that while trying to solve the problem of abusive religion, it may be an avenue where new and challenging problems may emerge. Cognisant of this and in light of the above recommendation, I suggest a collective approach among all stakeholders to spell out how far the government can regulate religion without infringing upon freedom of religion, while protecting its citizens from thuggery hidden in religious practices.

\subsection{Reintroduction of Religion in Schools}

The curriculum in basic education has underplayed the role of religious education (Dube and Hlalele 2017). Religion no longer occupies a central place in the curriculum, which, to our view, presents challenges. Among many challenges is that the curriculum produces learners that are not 
critical when it comes to religious issues. As such, it becomes easy for individuals to manipulate religious issues cognisant that the general populace or religious adherents have inadequate religious knowledge. Our argument is that new forms of religions can easily be problematised if schools afforded learners an opportunity to interrogate religions within an academic space. Again, if schools taught religion, learners were going to engage effectively with religious movements such as Gabola church, to an extent that learners or religious people can join the church based on critical examination. The classroom will allow a space for critical religious engagement as the only safe way that society can escape from religious criminals.

\subsection{Training of Religious Leaders on Human Rights}

Apart from the regulation of religion in South Africa, I am of the view that there is a need for training of religious leaders on issues of human rights, democracy, and the basics of governance. If possible, these should be a prerequisite for leading or starting a religious movement. Again, apart from calling to ministry, there is a need for professionalisation of pastoral calling, so that while one is responding to the call, one is cognisant of ethical and professional standards that must be adhered to when leading people. I advocate this because various religious movements have been on record for promoting practices that are questionable, making religion a much-contested phenomenon in South Africa. Professionalisation of the calling can go a long way to address other challenges that made religion a headache rather than a solution to the South African problem.

\section{Conclusions}

In conclusion, through this article I ignite the need for religious members prone to social justice, equity, and equality to be always vigilant and never to adopt a complacent view towards the persistence of global imperial designs underpinning asymmetrical global power relations (Dastile and Ndlovu-Gatsheni 2013), especially when they are sugarcoated through religious narratives. While there are mixed feeling on Gabola church, I am of the view that it is high time that religion be regulated through a thorough consultative manner to avoid infringement of the constitutional right of freedom of religion, while, at the same time, there is a need for the governments to protect citizens. Bringing back religion in schools will enable learners to interrogate new movements such as Gabola church in academic space with the intention of evoking and creating religions that will contribute to the promotion of human rights, sustainable development, and the emancipation of the people of South Africa.

Funding: This research received no external funding.

Conflicts of Interest: The author declares no conflict of interest.

\section{References}

Adamo, David T. 2011. Christianity and the African traditional religion(s): The postcolonial round of engagement. Verbum et Ecclesia 32: 285. [CrossRef]

Alvesson, Mats, and Hugh Willmott. 1992. On the idea of emancipation, management and organization studies. Academic of Management Review 17: 432-54. [CrossRef]

Beyers, Joco. 2014. The church and the secular: The effect of post-secular on Christianity. HTS Teologiese Studies/Theological Studies 70: 1-12. [CrossRef]

Birt, Linda, Suzanne Scott, Debbie Cavers, Christine Campbell, and Fiona Walter. 2016. Member checking: A tool to enhance trustworthiness or merely a nod to validation. Qualitative Health Research 26: 1802-11. [CrossRef] [PubMed]

Bottoms, Bette L., Michael Nielsen, Rebecca Murray, and Henrietta Filipas. 1995. Religion-related child physical abuse: Characteristics and psychological outcomes. Journal of Aggression, Maltreatment, and Trauma 8: 1-11. [CrossRef] 
Bradley, Wright. 2012. Bad news about the good news. The construction of Christian-failure narrative. Journal of Religion and Society 14: 1-19.

Brittain, Christopher C. 2012. The Frankfurt school of religion. Religion Compress 6: 204-12. [CrossRef]

Bygstad, Bendik, and Bjorn Erick Munkvold. 2007. The Significance of Member Checking Validation in Qualitative Sanalysis: Experiences from a Longitudinal Case Study. Available online: https:/ / core.ac.uk/download/ pdf/52058218.pdf (accessed on 31 March 2018).

Chidester, David. 2003. Salvation and Suicide. Jim Jones: The Peoples' Temple and Jonestown. Indiana: Indiana University Press.

Cornwall, Andrea, and Rachel Jewkes. 1995. What is participatory action research? Social Science and Medicine 41: 1666-76. [CrossRef]

CRL. 2015. CRL Rights Commission's Preliminary Report of the Hearings on Commercialisation of Religion and Abuse of People's Belief Systems. Available online: http:/ / www.crlcommission.org.za/docs/Preliminary\% 20Report \%20of\%20the\%20hearings\%20on\%20Commercialization\%20of\%20Religion.pdf (accessed on 20 March 2018).

Damaris, Parsitau, and Adriaan van Klinken. 2018. Pentecostal intimacies: Women and intimate citizenship in the ministry of repentance and holiness in Kenya. Citizenship Studies 22: 586-602.

Dastile, Nontyatyambo Pearl, and Sabelo Jeremiah Ndlovu-Gatsheni. 2013. Power, knowledge, and being decolonial combative discursive as a survival kit for Pan-Africanists in the 21th century. Alternation 20: 105-34.

Dayiman, Malibongwe, and Sikho Ntshobane. 2018. We Didn't Know, Say Ngcobo Church Followers, SowetanLive. Available online: www.sowetanlive.co.za/news/southafrica/2018-02-26-we-didnt-knowsay-church-followers / (accessed on 13 March 2018).

Donald, Alice, and Erica Howard. 2015. The Right to Freedom or Belief and Its Intersection with Other Rights. Available online: www.ilga-europe.org/sites/default/files/Attachments/the_right_to_freedom_ of_religion_or_belief_and_its_intersection_with_other_rights_0.pdf (accessed on 13 March 2018).

Dreyer, Jaco. 2007. Religion and State in the Post Colonial Africa: Challenges and Opportunities. Pretoria: University of South Africa.

Dube, Bekithemba. 2019. Conundrum of religious mafia and legislation in South Africa. When does religion become a national threat? Reference to the Seven Angels Ministry. Verbum et Ecclesia 40: 1-10. [CrossRef]

Dube, Bekithemba, and Dipane Hlalele. 2017. Reconceptualising the interface of religion and school violence towards construction of sustainable learning ecologies in South Africa. Theologia 41: 1-22.

Dube, Bekithemba, and Molebatsi Milton Nkoane. 2018. The interface of politics and religion in Zimbabwean politics: Rethinking religious leaders as agents of consecration and repudiation. Alternation Special Edition 23: 224-43. [CrossRef]

Dube, Bekithemba, Nkoane Molebatsi Milton, and Hlalele Dipane. 2017. The ambivalence of freedom of religion and unearthing the unlearnt lessons of religious freedom from the Jonestown Incident: A decolonial approach. Journal of the Study of Religion 30: 330-49. [CrossRef]

Epondo, Peter. 2015. "Con" Pastors Thrive as Africans Become Increasingly Desperate for Miracles. Mail and Guardian Voices of Africa. Available online: http:/ /voicesofafrica.co.za/con-pastors-thrive-africans-becomeincreasingly-desperate-miracles / (accessed on 23 July 2018).

Freire, Paulo. 2000. Historical Conditioning and Levels of Consciousness. The Politics of Education, Culture of Silence. London: Bergi and Garvey.

Gunawan, Joko. 2015. Ensuring trustworthiness in qualitative research. Nursing Journal 1: 10-11. [CrossRef]

Hertzke, Allen. 2012. Religious Freedom in the World Today: Paradox and Promise. Acta 17: 1-12.

Jared, Too. 2017. The Church of Gabola Where Booze Flows Freely. Available online: www.sde.co.ke/article/ 2001259113/the-church-of-gabola-where-booze-flows-freely (accessed on 12 October 2018).

Kaunda, Chammah, and Mutale Kaunda. 2018. Mobilising religious assets for social transformations: A theology of decolonial reconstruction perspective on the ministry of national guidance and religious affairs (MNGRA) in Zambia. Religions 9: 176. [CrossRef]

Kemmis, Stephens, and Robin McTaggart. 2007. Communicative action and public sphere. In The SAGE Handbook of Qualitative Research. Thousand Oaks: Sage, pp. 559-603. 
Kenny, Ruth. 2017. South African Church of God Where God Worship and Alcohol Go Hand in Hand. Available online: www.odditycentral.com/news/south-africans-church-of-drinking-where-god-worshipand-alcohol-go-hand-in-hand (accessed on 22 October 2018).

Kwalimva, David. 2017. Welcome to Gabola Church Where you Are Baptised by Your Favourite Beer. Available online: www.nairobinews.co.ke.national/life/welcome-gabola-church-where-you-are-baptised-by-yourfavourite-beer (accessed on 22 October 2018).

Laws, Sofie, Caroline Harper, and Rachel Marcus. 2003. Research for Development. London: Sage.

Loewenson, Rene, Asa C. Laurell, Christer Hogstedt, Lucia D'Ambruoso, and Zubin Shroff. 2014. Participatory Action Research in Health Systems: A Methods Reader. Harare: International Development Research Centre.

Lopez, Lori Kido. 2015. A media campaign for ourselves: Building organisational capacity through participatory action research. Journal of Media Practice 16: 228-24. [CrossRef]

Lunn, Jenny. 2009. The role of religion, spirituality and faith in devil. A critique theory approach. Third World Quarterly 30: 937-51. [CrossRef]

Makhethwa, Tankiso. 2017. Gabola Church Founder Is Army Nurse. Available online: www.sowetanlive.co.za/ news/south-africa/2017-12-18-gabola-church-founder-is-army-nurse (accessed on 12 October 2018).

Mathape, Gosebo. 2018. Boozing Gabola Church Bishop to Be Ordained as Pope of Africa. Available online: www. citizens.co.za/news/news-eish/1869900/boozing-gabola-church-to-be-ordained-as-a-pope-of-africa (accessed on 12 October 2018).

Mignolo, Walter. 2007. Delinking. Cultural Studies 21: 449-514. [CrossRef]

Molobi, Stephens. 2017. Gabola Church Founder under Fire. Available online: www.dailysun.co.za/news/ national/gabola-church-founder-under-fire-20171122 (accessed on 12 October 2018).

Monychenda, Heng. 2008. Social Justice in Inter-Religious Perspectives. Cambodia: Konrad Adenauer Foundation.

Mpofu, William. 2017. Decoloniality as a Travelling or What Decoloniality is Not. Available online: www.wiser. wits.ac.za/systems/files/seminar/mpofu2017/pdf (accessed on 20 April 2018).

Ndlovu-Gatsheni, Sabelo Jeremian. 2015. Decoloniality in Africa. A continuing search for a new world order. Australian Review of African Studies 36: 22-50.

Ramón, Grosfoguel. 2011. Decolonizing Post-Colonial Studies and Paradigms of Political Economy. Transmodernity, decolonial thinking and global coloniality. TRANSMODERNITY: Journal of Peripheral Cultural Production of the Luso-Hispanic World 1: 1-38.

Reginald, Alva. 2017. The catholic church perspective of human dignity as the basis of challenges with the secular world. Stellenbosch Theological Journal 3: 221-41.

Republic of South Africa. 1998. Constitution of the Republic of South Africa. Available online: www.justice.gov. za/legislation/constitution/SAConstitution-web-eng-02.pdf (accessed on 20 April 2018).

Tau, Poloko. 2017. Drink for God. Available online: www.news24.com/southafrica/news/drink-for-god-20171031 (accessed on 23 October 2018).

Tshelane, Maloudi David. 2013. Participatory action research and construction of academic identity among postgraduate research students. The Journal of Transdisciplinary Research in South Africa 9: 413-29. [CrossRef]

UNESCO. 2011. Making Textbook Content Inclusive: A Focus on Religion, Gender and Culture. Fontenoy: United Nation Educational Scientific and Cultural Organization (UNESCO).

Williams, Bronwyn T., and Mary Brydon-Miller. 2004. Changing directions: Participatory action research, agency, and representation. In Ethnography Unbound: From Theory Shock to Critical Praxis. Albany: State University of New York Press, pp. 241-57.

Zondi, Siphamandla. 2016. A decolonial turn in diplomatic theory: Unmasking epistemic injustice. Journal of Contemporary History 4: 18-37. [CrossRef]

(c) 2019 by the author. Licensee MDPI, Basel, Switzerland. This article is an open access article distributed under the terms and conditions of the Creative Commons Attribution (CC BY) license (http:/ / creativecommons.org/licenses/by/4.0/). 